\title{
Otological Diseases amongst Elderly Patients in Port Harcourt, Nigeria- A 15 Years Review
}

\author{
Onotai Lucky Obukowho ${ }^{1 *}$ and Ureh Oparaodu ${ }^{2}$ \\ ${ }^{1}$ Department of ENT Surgery UPTH, Port Harcourt, Africa \\ ${ }^{2}$ Department of Ear Nose and Throat Surgery, UPTH, Port Harcourt, Africa
}

Submission: March 23, 2016; Published: March 30, 2017

*Corresponding author: Lucky Obukowho Onotai, Department of ENT Surgery, University of Port Harcourt Teaching Hospital (UPTH), Port Harcourt, Rivers State. Nigeria, Email: onotailuckinx@yahoo.co.uk

\begin{abstract}
Background: Ageing is among the greatest known risk factors for most human diseases. It is associated with a lot of health challenges. There is scarcity of literature on otological diseases in the elderly patients in our environment. Thus this study was done to document the pattern of otological diseases amongst elderly patients as seen in Port Harcourt, Nigeria. The knowledge from this study will help healthcare policy makers in their planning and delivering of healthcare services to the senior citizens of Nigeria as well as promote cost effective treatment of their otological diseases.
\end{abstract}

Patients and Methods: This is a 15 years retrospective review of patients aged 60 years and above seen between January 2001 and December 2015 at the Ear, Nose and Throat (ENT) Surgery Department of the University of Port Harcourt Teaching Hospital (UPTH). The following patients' data were documented and analyzed for age, gender, clinical presentation, investigations, diagnosis and treatment modalities. The data were entered into SPSS version 16 computer software and analyzed descriptively.

Results: A total of 1,512 patients out of patient population of 22,800 were found to be 60 years and above. The geriatric population was thus $6.63 \%$ of our total patients. Otological problems accounted for $846(55.95 \%)$ cases. Cerumen auris was the commonest otological ( $\mathrm{n}=255$, $30.14 \%$ ) presentations, followed by Otomycosis Externa ( $n=236,27.89 \%)$, presbyacusis ( $n=205,24.23 \%)$ and CSOM $(n=94,11.11 \%)$.

Conclusion: This study has established the pattern of otological diseases amongst the elderly patients as seen recently in our environment and this does not differ from what has been reported elsewhere. Majority of the patients had cerumen auris. We therefore recommend that more facilities \& resources be provided to take care of the otological diseases of the elderly in our environment.

Keywords: Survey; Otological diseases; Elderly patients; Port Harcourt; Nigeria

\section{Introduction}

Aging is a natural process that occurs in all humans, it affects all the organs of the body including the ear [1]. Aging process affecting the ears is usually not life threatening when compared to other medical diseases that affect the respiratory and cardiovascular systems of the body [1,2]. Ageing has been described as a "global phenomenon,» that occurs fastest in developing countries, including those with large youth populations, and poses social and economic challenges to the work which can be overcome with «the right set of policies to equip individuals, families and societies to address these challenges and to reap its benefits [2-6].

In the developing countries such as ours young people age faster probably due to poverty and environmental factors while the elderly people have a shorter life expectancy compared to their counterparts in the developed World. This was also part of the reason we decided to consider patients who are 60 years and above for this study [3-6]. The ear which is the sense organ of hearing consists of the outer, middle and inner part. Each of which plays an important role in hearing. With increasing age, there is degeneration of the tissues which makes the individual more prone to diseases of the ear such as presbyacusis and impacted wax just to mention a few [7,8]. Obviously, with the presence of elderly people in our population there will always be the need to make provision to tackle their healthcare needs and challenges [9]. Knowledge of the pattern of their otological diseases will no doubt be useful to the government when formulating healthcare policies to cater for their needs. Moreover, there is scarcity of literature on otological diseases in the elderly patients in our environment. Thus; this study is carried to document the pattern of otological diseases amongst elderly patients seen in Port Harcourt, Nigeria. 


\section{Global Journal of Otolaryngology}

\section{Patients and Methods}

This is a retrospective review of patients aged 60 years and above seen between January 2001 and December 2015 at the Ear, Nose and Throat (ENT) Surgery Department of the University of Port Harcourt Teaching Hospital (UPTH). The material resource for this review was principally the outpatient's records of the Ear Nose and Throat Department of UPTH. Ward admission records and Theater records augmented this. The following patients' data were documented and analyzed for age, gender, clinical presentation, investigations done, diagnosis and treatment modalities. The data were entered into SPSS version 16 computer software and analyzed descriptively.

\section{Results}

A total of 1,512 patients out of a patient population of 22,800 were found to be 60 years and above. The geriatric population was thus $6.63 \%$ of our total patients. Eight hundred and forty six patients were found to have otological diseases. There were 384 males and 462 females giving M: F ration of 1:1.2. The age range was 60 -95 years. The commonest age group that was affected was 66-71 years $n=364,43.03 \%$ (Table 1 ). Cerumen auris was the commonest otological $(n=255,30.14 \%)$ presentation followed by Otomycosis Externa $(\mathrm{n}=236,27.89 \%)$, presbyacusis $(\mathrm{n}=205,24.23 \%)$ and CSOM (n=94, 11.11\%) (Table 2).

Table 1: Age distribution.

\begin{tabular}{|c|c|c|}
\hline Age range & Number & Percentage (\%) \\
\hline $60-65$ & 297 & 35.11 \\
\hline $66-71$ & 364 & 43.03 \\
\hline $72-77$ & 104 & 12.29 \\
\hline $78-83$ & 46 & 5.44 \\
\hline $84-89$ & 25 & 2.96 \\
\hline $90-95$ & 10 & 1.18 \\
\hline Total & $\mathbf{8 4 6}$ & $\mathbf{1 0 0}$ \\
\hline
\end{tabular}

Table 2: Otological Presentation.

\begin{tabular}{|c|c|c|}
\hline Diagnosis/Symptom & Number & Percentage (\%) \\
\hline Neoplasm of ear & 3 & 0.35 \\
\hline Otosclerosis & 3 & 0.35 \\
\hline $\begin{array}{c}\text { Traumatic Perforation of tympanic } \\
\text { membrane }\end{array}$ & 6 & 0.71 \\
\hline Eustachian Dysfunction & 5 & 0.59 \\
\hline Foreign body & 5 & 11.11 \\
\hline Chronic Suppurative Otitis Media & 94 & 30.14 \\
\hline Cerumen Auris & 255 & 0.59 \\
\hline Vertigo & 5 & 24.23 \\
\hline
\end{tabular}

\begin{tabular}{|c|c|c|}
\hline Otomycosis Externa & 236 & 27.89 \\
\hline Otitis Externa & 4 & 0.47 \\
\hline Acute Suppurative Otitis Media & 9 & 1.06 \\
\hline Meniere's Disease & 10 & 1.18 \\
\hline Tinnitus & 3 & 0.35 \\
\hline Facial N. Palsy. (Bell's) & 3 & 0.35 \\
\hline Total & $\mathbf{8 4 6}$ & $\mathbf{1 0 0}$ \\
\hline
\end{tabular}

\section{Discussion}

The World Health Organization has fixed 65years and above as geriatric age group. Our choice of 60 years for the beginning of geriatric age group was informed by the fact that the average life expectancy of the Nigerian is still less than 60 years [3-5]. In this study the elderly patients had a prevalence of $6.63 \%$. However, in a previous study by Okoye and Onotai in 2007 they found a prevalence of $4.7 \%$ [6]. The reason for the increase in the prevalence in this study can be attributed to the number of years involved in this present review which is 5 years more than the previous study. Furthermore, other researchers like Okhakhu et al. $[9,10]$ in Benin City found a prevalence of $6.2 \%$ while Ogunleye et al. $[9,10]$ in Ibadan found a much lower prevalence of $3.64 \%$. The reasons for the difference in the prevalence may vary because of either ethnicity or study design as previously mentioned.

Meanwhile, reports from Europe and Asia show a higher prevalence of their elderly patient population. Calvo et al. $[12,13]$ reported elderly patients making up to $30 \%$ of their ENT Clinic population in Spain while Bunnag et al. $[12,13]$ reported that $16.3 \%$ of elderly Thai citizens presented with otological diseases to them. Our study found the female elderly patients to have more otological diseases. The findings of Okhakhu et al. [9] in Benin-City agrees with our findings while the findings of Ogunlenye et al. [9] in Ibadan and that of Kayode et al. [2,10] in Ilorin found more male patients who presented with otological diseases in their setting.

The age group that was commonly affected in our study was 66-71years which does not differ from the findings of other researchers $[2,9,10,14,15]$. It is interesting to note that cerumen auris was the commonest otological disease recorded in our series which agrees with the finding of Kayode et al. $[2,9,10]$ in Ilorin, while Ogunleye et al. [2,9,10] and Okhakhu et al. [2,9,10] found presbyacusis as the commonest otological presentation in their series. In the international scenes Bunnag et al. $[2,9,10]$, in Thailand reported that $12.5 \%$ of their elderly population had external ear pathologies while only $2.7 \%$ had middle ear pathologies. Calvo et al. [11,12] reported that Cerumen auris was the commonest pathology that affected the elderly patients in Spain. Otomycosis Externa was the second most common otological disease encountered in our series and this could be explained by the high humidity and high temperature of our environment. Okoye and Onotai also found otomycosis to be the 
second most common otological disease of the elderly in 2007 [6].

The Chronic Suppurative Otitis Media found in our series was not a surprise because Okoye and Onotai in their series found CSOM to be the commonest otological presentation and their explanation was that the CSOM in most of their patients may have persisted since childhood as noted by Okafor in Enugu and Bhatia in Jos $[6,16,17]$. Other researchers also reported CSOM as part of the otological diseases found amongst the elderly in their series [2,9]. The other otological diseases found amongst the elderly patients in our series include foreign body impaction in the external auditory canal, neoplasm of the external ear, otosclerosis and facial nerve palsy just to mention but a few. These findings have been documented by other researchers as well $[2,9,16,17]$. Even though, they may not top the list as common otological diseases found among the elderly in our environment they should be given prompt attention as well.

\section{Conclusion}

This study has established the pattern of otological diseases seen recently amongst the elderly in our environment and this does not differ significantly from what has been reported globally. Majority of the patients had cerumen auris, followed by otitis externa and presbyacusis. We therefore, recommend that more facilities and resources should be provided to take care of these common otological diseases of the elderly in our environment to improve their quality of life.

\section{References}

1. Dillin A, Gottschling DE, Nyström T (2014) The good and the bad of being connected: the integrons of aging. Curr Opin Cell Biol 26: 107112 .

2. Kayode AS, Alabi BS, Segun-Busari S, Ogah AS (2010) Audit of Otological Diseases amongst Elderly in Nigeria. Intl Arch Otorhinolaryngol São Paulo - Brazil 14(2): 212-216.

3. Shapiro DP (1999) Geriatric demographics and the practice of Otolaryngology. Ear, Nose, Throat J 78(6): 418-421.
4. UNICEF at a glance (2016) Nigeria statistics.

5. (2016) The World Fact Book.

6. Okoye BC, Onotai LO (2007) Pattern of geriatrics otolaryngological diseases in Port Harcourt. Niger J Med 16(3): 239-241.

7. (2008) Basic anatomy of the ear and the physiology of hearing: $\left(7^{\text {th }}\right.$ edn). Scott-Brown Otolaryngology Head and Neck Surgery 3(19): 3103-3298.

8. (2008) Diseases of the ear and their clinical presentation: ( $7^{\text {th }}$ edn). Scott-Brown Otolaryngology Head and Neck Surgery 3(19): 33113526.

9. Okhakhu AL, Okolugbo NE, Onyeagwara NC (2013) Pattern of otolaryngological disorders amongst geriatric population in Benin City, Nigeria. IJMAMR 1: 14-19.

10. Ogunleye AOA,IbekweTS, Ijaduola GTA (2005)Otorhinolaryngologyand Geriatrics in Ibadan, Nigeria. Nigerian Journal of Otorhinolaryngology 2(1): 7-12.

11.E Calvo Boizas, A Rodrguez Gutiérrez, F Gómez Toranzo (1999) Care for elderly patients at am ENT clinic. Descriptive study. Acta otorhinolarygol ESP 50(1): 56-59.

12. Chaweewan Bunnag, Suchitra Prasansuk, Apinan Na Nakorn, Perapun Jareoncharsri, Suvajana Atipas, et al. (2002) Ear diseases and hearing in the Thai elderly population part I. A comparative study of the Accuracy of diagnosis and treatment by General practitioners Vs ENT specialists. J Med Assoc Thai 85(5): 52 -531.

13. Bunnag C, Prasansuk S, Nakorn AN, Jareoncharsri P, Atipas S, et al. (2002) Ear diseases and hearing in the Thai elderly population, A one year follow-up study. J Med Assoc Thai 85(5): 532-539.

14. Ologe FE, Segun-Busari S, Abdulraheem IS, Afolabi AO (2005) Ear diseases in elderly hospital patients in Nigeria. J Gerontol Biol Sci Med Sci 60(3): 404-406.

15. Ezeanolue BC, Obasikene G (2005) Pattern of otorhinolaryngological disorders seen in geriatric patients at a private otorhinolaryngology clinic in Enugu. Nigeria Journal of otorhinolaryngology 2(1): 13-16.

16. Okafor BC (1983) Otolaryngology in south-eastern Nigeria. Pattern of diseases of the ear. Niger Med J 13: 11-19.

17. Bhatia PL, Verughese R (1987) Pattern of Otolaryngological diseases in Jos community. Niger med J 17: 67-73.

\section{Your next submission with Juniper Publishers will reach you the below assets}

- Quality Editorial service

- Swift Peer Review

- Reprints availability

- E-prints Service

- Manuscript Podcast for convenient understanding

- Global attainment for your research

- Manuscript accessibility in different formats

( Pdf, E-pub, Full Text, Audio)

- Unceasing customer service

Track the below URL for one-step submission https://juniperpublishers.com/online-submission.php 